\title{
Temperature limits to activity, feeding and metabolism in the Antarctic starfish Odontaster validus
}

\author{
Lloyd S. Peck*, Karen E. Webb, Andrew Miller, Melody S. Clark, Tim Hill \\ Natural Environment Research Council, British Antarctic Survey, High Cross, Madingley Road, Cambridge CB3 0ET, UK
}

\begin{abstract}
Cold-blooded Antarctic marine species are highly stenothermal and possibly the most temperature-sensitive group on Earth. Studies to date have produced upper lethal temperatures in the range of 4 to $10^{\circ} \mathrm{C}$. Although invertebrates have not been acclimated to temperatures above $3^{\circ} \mathrm{C}$, some Antarctic fish have been acclimated to $4^{\circ} \mathrm{C}$. Activity competence has been evaluated in several Antarctic marine invertebrates and shown to be very sensitive to temperature, with $50 \%$ failures in the range of 1 to $3^{\circ} \mathrm{C}$ for clams, limpets and scallops. The starfish Odontaster validus is much more capable of coping with elevated temperatures than any of these species. Turning speed increased with temperature, reaching a maximum at $7.5^{\circ} \mathrm{C}$. Temperature increase led to a clear hierarchy of response loss in the starfish, with lethal limits occurring at a higher temperature $\left(15^{\circ} \mathrm{C}\right)$ than loss of activity $\left(9^{\circ} \mathrm{C}\right)$ and loss of feeding competence (Specific Dynamic Action, or SDA) and coelomic oxygen level collapse both occurring at $6^{\circ} \mathrm{C}$. The higher temperature limit for activity than coelomic oxygen level could be explained by body design or taxonomic factors, which may also explain the markedly enhanced ability to cope with elevated temperature over other Antarctic marine species. Long-term acclimation and survival up to $6^{\circ} \mathrm{C}$ should be possible for this species, which is important for species living on the west coast of the Antarctic Peninsula, possibly the fastest warming marine environment on Earth. The markedly higher resistance to elevated temperature and maintenance of function in a common Antarctic predator compared to the abilities of several of its prey species suggests that a warming environment could have dramatic consequences on the community-level ecological balance for large areas of the Antarctic benthos.
\end{abstract}

KEY WORDS: Aerobic scope · Climate change · Specific Dynamic Action · SDA · Critical temperature $\cdot$ Temperature change $\cdot$ Competition

\section{INTRODUCTION}

Antarctic marine species are highly stenothermal, with the vast majority having experimental upper lethal temperatures between 5 and $10^{\circ} \mathrm{C}$ (Somero \& DeVries 1967, Peck \& Conway 2000). The most stenothermal species can only survive in a temperature window between -2 and $4{ }^{\circ} \mathrm{C}$ (Peck 1989, Pörtner et al. 1999a). The physiological processes setting the temperature tolerance limits, at least in marine ectotherms, are associated with reductions in whole animal aerobic scope (Pörtner et al. 1998, 1999b, Peck et al. 2002). Recently, Pörtner (2002) elucidated the physiological basis of temperature limits at different levels and showed a hierarchy of tolerance from the molecular level to the whole animal. This showed that the tightest limits were set at the whole animal level. There is then wider tolerance at each step down the physiological hierarchy to tissues, cells and molecules, and he argued that, in general, adding organismal complexity reduces thermal tolerance. Thus, the physiological processes evident in response to varying temperature, at least in acute to medium-term experiments, are a progressive reduction in aerobic scope to a point where it is lost completely and tissues transfer to anaerobic metabolism. This is the critical physiological 
limit of Pörtner et al. (1998), and this may have a basis in mitochondrial function (Pörtner et al. 2007). Beyond this point survival is dictated by organismal tolerance to anaerobiosis.

In longer-term studies, several Antarctic fish species have been shown to be able to acclimate to $4^{\circ} \mathrm{C}$ but not above this temperature (Gonzalez-Cabrera et al. 1995, Lowe \& Davison 2005, Seebacher et al. 2005, Jin \& DeVries 2006, Podrabsky \& Somero 2006). Invertebrates, however, appear less able to acclimate to elevated temperatures; attempts to acclimate the scallop Adamussium colbecki to temperatures above $2{ }^{\circ} \mathrm{C}$ failed (Bailey et al. 2005). In long-term temperature elevation trials the brachiopod Liothyrella uva survived at $3.0^{\circ} \mathrm{C}$ but failed at $4.5^{\circ} \mathrm{C}$ (Peck 1989) and the bivalve Limopsis marionensis failed at $4^{\circ} \mathrm{C}$ (Pörtner et al. 1999a). Attempts to acclimate the clam Laternula elliptica (S. Morley pers. comm.) and the brittle star Ophioniotus victoriae (M. Clark pers. obs.) to $3^{\circ} \mathrm{C}$ have also failed.

The important criteria for population or species survival in a given area is not, however, dictated directly by its physiological tolerance limits, but by the ecophysiological constraints on its ability to perform critical biological functions such as feeding, locomotion and reproduction, and how changes in these characteristics, affect ecological balances. Recently, investigations of activity in a range of Antarctic marine herbivores indicated a surprising sensitivity to temperature and a progressive decline in capability consistent with declining aerobic scope (Peck et al. 2004). The large infaunal bivalve mollusc Laternula elliptica has an experimental upper lethal temperature of $9^{\circ} \mathrm{C}$ and transfers to anaerobic metabolism at ca. $6^{\circ} \mathrm{C}$ (Peck et al. 2002). However, it ceases to rebury after removal from sediment at $5^{\circ} \mathrm{C}$, and $50 \%$ of the population loses this ability when temperatures reach $2.5^{\circ} \mathrm{C}$ (Peck et al. 2007). Likewise, the limpet Nacella concinna has an upper lethal temperature of $9.5^{\circ} \mathrm{C}$ (Peck 1989), but $50 \%$ of the population loses the ability to right themselves when turned over at ca. $2^{\circ} \mathrm{C}$, and the scallop Adamussium colbecki dies at 5 to $6^{\circ} \mathrm{C}$, but loses the ability to swim between 1 and $2^{\circ} \mathrm{C}$. These are all major activities that involve extensive muscular activity.

The Antarctic has an abundant and rich benthos with high levels of endemicity (Arntz et al. 1994, Clarke \& Johnston 2003). Current data for invertebrates suggest that they are highly sensitive to rising temperatures, but analyses to date are limited to herbivores or scavengers. To move analyses to other trophic levels and identify ecologically important relations, we evaluated the ability to perform work, metabolism, aerobic status and feeding, including Specific Dynamic Action (SDA) of feeding, with rising temperature in a common predatory species, the starfish Odontaster validus. O. validus is common in Antarctica, circumpolar and a major element of the predator/scavenging organism complex of the benthic food web. A better ability to cope with rising temperature than species it preys upon, including scallops, limpets and burrowing bivalves, may significantly alter the ecological balance during any future environmental warming event. This is the first step towards making ecologically relevant predictions of climate change effects based on temperature tolerance capacities of different ecological guilds for a region where significant change has already been documented and the fauna appear sensitive to change.

\section{MATERIALS AND METHODS}

Odontaster validus were collected by SCUBA from sites at 10 to $20 \mathrm{~m}$ depth near the British Antarctic Survey's Rothera research station, Adelaide Island, Antarctica $\left(67^{\circ} 34^{\prime} 07^{\prime \prime} \mathrm{S}, 68^{\circ} 07^{\prime} 30^{\prime \prime} \mathrm{W}\right)$. For experiments on whole animal oxygen consumption, coelomic oxygen content and activity in relation to temperature, specimens were held in a flow-through aquarium at conditions close to ambient for 2 to $3 \mathrm{wk}$ before being transported to the UK. In transit and in the UK, starfish were held in recirculating seawater systems at $0 \pm$ $1.5^{\circ} \mathrm{C}$, in a $12: 12 \mathrm{~h}$ light:dark regime, and fed either frozen krill or fish. Measurements of the effect of temperature on the post-prandial rise in metabolic rate were made in Antarctica in the station flow-through aquarium, where temperatures were within $0.5^{\circ} \mathrm{C}$ of ambient.

Turning activity in relation to temperature. Prior to initiating investigations of ability of species to right themselves (turn the right way up) in relation to temperature, specimens were starved for a minimum of $3 \mathrm{wk}$ to ensure individuals had low resting metabolic rates. Groups of between 5 and 10 starfish were then transferred to jacketed tanks connected to thermocirculator units, and the whole system was held in a controlled-temperature room. In this fashion, temperatures were held at the set temperature $\pm 0.1^{\circ} \mathrm{C}$. Initially, temperatures were held at $0.3^{\circ} \mathrm{C}$. Temperatures were then changed at a rate of 0.1 to $0.2^{\circ} \mathrm{C} \mathrm{h}^{-1}$ until the required experimental temperature was reached. Specimens were allowed $24 \mathrm{~h}$ to acclimate at each temperature before experiments began. In each experiment, starfish were turned upside down, and the time taken for them to right themselves was recorded. Starfish were well spread in the tanks to avoid the possibility of interference or interactions affecting results. Each starfish was inverted up to 26 times at 0.3 and $9.5^{\circ} \mathrm{C}$ to evaluate any effect of fatigue. At other temperatures, 5 starfish were inverted between 7 and 12 times. Turning rate was calculated as the reciprocal of 
the number of minutes needed for an individual to right itself.

Metabolism and temperature. For all oxygen consumption experiments in the UK, specimens were starved for 4 wk prior to measurements being made to ensure that metabolic rates were close to standard. The specimens were then transferred to temperature control systems similar to those described above. Whole animal oxygen consumption measures were made using closed bottle respirometry methods similar to those of Chapelle \& Peck (1995). Preliminary trials were run to assess suitable times to run experiments, and oxygen concentrations were not allowed to fall below $70 \%$ saturation. Experiments were run using $1 \mu \mathrm{m}$ filtered, aerated seawater. Animal volumes were measured by displacement after trials and respirometer volume adjusted accordingly in the calculation of oxygen consumption rate. Oxygen concentrations in chambers were obtained from $25 \mu \mathrm{l}$ samples taken with a gas tight syringe through a rubber septum seal. These samples were injected into a fuel cell-based couloximeter, which measured oxygen content of the sample to $\pm 1 \%$ (Peck \& Uglow 1990, Peck \& Whitehouse 1992). Replicate samples were taken to ensure accuracy. Five starfish of similar size were selected for this experiment and their rates of oxygen consumption measured at $-1.5,0,3,6,9$ and $12^{\circ} \mathrm{C}$. After each temperature rise oxygen consumption was measured daily, and the move to the next temperature step was made when respiration rates appeared to have stabilised. The experiment was terminated at $15^{\circ} \mathrm{C}$ when $>50 \%$ of the starfish had died.

Oxygen content of coelomic fluid was obtained from replicate $25 \mu \mathrm{l}$ samples taken from the coelomic cavity through the epidermis using a gas tight syringe. These samples were also analysed using a couloximeter. For measures of coelomic fluid oxygen content, separate individuals were used from those in the respirometry trials. These individuals were, however, held in the same temperature control system and therefore under identical conditions.

Feeding and SDA. These trials were conducted in Antarctica on 75 freshly collected specimens held in flow-through aquaria at temperatures between 0.5 and $0.9^{\circ} \mathrm{C}$, which were close to but slightly above ambient $\left(0.3\right.$ to $\left.0.6^{\circ} \mathrm{C}\right)$. Initially, specimens were starved for $4 \mathrm{wk}$ to exclude any effects of prior feeding. The first experiment evaluated the temperature at which feeding ceased. Experiments started by transferring 48 starfish to the temperature control system and initially, at $0^{\circ} \mathrm{C}$, they were individually fed blocks of fish muscle (Notothenia coriiceps), ca. 10\% of their own wet body weight to ensure that all individuals would take food. After $48 \mathrm{~h}$ all uneaten food was taken from each starfish and weighed. Specimens were then held for
$10 \mathrm{~d}$ without food to ensure the initial feeding at $0^{\circ} \mathrm{C}$ would not affect readiness to feed. In subsequent trials 8 specimens were placed in the temperature control system and temperatures raised at $0.5^{\circ} \mathrm{C} \mathrm{h}^{-1}$ until the required temperature was reached. They were then allowed to acclimate to the new temperature for $24 \mathrm{~h}$ before being offered food (ca. $10 \%$ body weight). At all temperatures, food remaining after $48 \mathrm{~h}$ was removed and weighed, allowing the amount of food eaten by each individual to be obtained by subtraction. Different groups of 8 were used at each temperature step, to avoid any pretreatment effects. At temperatures where some or all individuals did not take the offered food, a different group of 8 individuals was tested for ability to feed $3 \mathrm{~d}$ after reaching the set temperature.

In the second experiment the increase in metabolism following SDA of feeding was assessed using a protocol similar to Peck (1996). Initially, 5 specimens were transferred to the temperature control system and held at $0^{\circ} \mathrm{C}$. Individuals were allowed $2 \mathrm{~d}$ to acclimate to the experimental conditions and then standard metabolism was measured as oxygen consumption over the next $3 \mathrm{~d}$ using the methods described above. They were then allowed to feed on meals of ca. $10 \%$ body weight for $48 \mathrm{~h}$, after which remaining food was removed and weighed. Oxygen consumption was then measured daily over the subsequent period of elevated metabolism. This whole process was then repeated on a new group of 5 starfish at $6^{\circ} \mathrm{C}$, the highest temperature at which all Odontaster validus fed in the feeding trials.

After trials were complete, starfish volumes were measured as before. Specimen live weight was obtained by weighing after surface drying, dry weight after drying for $24 \mathrm{~h}$ at $60^{\circ} \mathrm{C}$, and ash weight following ignition at $475^{\circ} \mathrm{C}$ for $24 \mathrm{~h}$. After drying and ashing, samples were allowed to cool in a desiccator prior to weighing.

Data were tested for normality prior to parametric analysis using the Anderson-Darling test, where appropriate. Statistical treatments were made using the MINITAB 14 package.

\section{RESULTS}

\section{Turning activity}

At $0^{\circ} \mathrm{C}$ the starfish took on average $4.7 \mathrm{~min}(\mathrm{SE}=$ 0.24 ) to right themselves after being turned over. There was a significant effect of size, with smaller starfish turning more rapidly than larger specimens (ANOVA, $F=3.95, \mathrm{p}<0.01, \mathrm{df}=111$ ). There was no discernible fatigue exhibited by the starfish being forced to right themselves repeatedly by turning them 


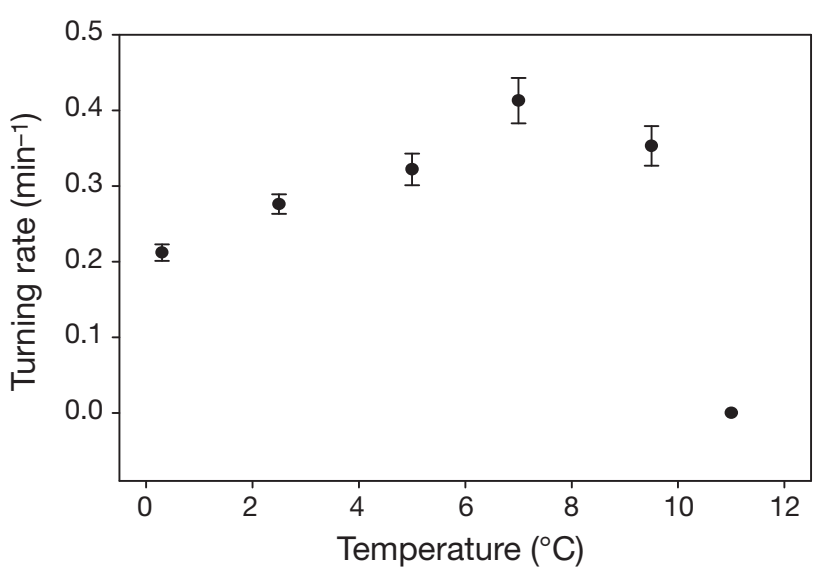

Fig. 1. Odontaster validus. Rate of turning from upside down versus temperature. Data shown are mean $( \pm \mathrm{SE})$. At each temperature 5 starfish were assessed, and 12 assessments were made on each starfish

back over immediately following righting at 0.3 or $9.5^{\circ} \mathrm{C}$ there was no change in the speed of turning (ANOVA, $F=0.74, \mathrm{p}=0.81, \mathrm{df}=362$ ).

Raising the temperature $(T)$ increased the turning rate (TR) of the Odontaster validus linearly from $0.21 \mathrm{~min}^{-1}$ at $0.3^{\circ} \mathrm{C}$ to $0.41 \mathrm{~min}^{-1}$ at $7.0^{\circ} \mathrm{C}(\mathrm{TR}=0.20+$ $0.029 T, \mathrm{r}^{2}=0.20, F=63.43, \mathrm{p}<0.001, \mathrm{df}=256$, Fig. 1). When temperatures were raised to $9.5^{\circ} \mathrm{C}$, the turning rate declined to $0.35 \mathrm{~min}^{-1}$. At all temperatures up to $7^{\circ} \mathrm{C}$, all starfish were capable of turning; at $9.5^{\circ} \mathrm{C}$, 1 specimen failed, and at $11.0^{\circ} \mathrm{C}$ no starfish were capable of righting themselves. At this temperature all starfish adopted a position where the arms were held raised above the body.

\section{Whole animal oxygen consumption, coelomic oxygen content and temperature}

The starfish used in this experiment were selected to be of similar size. They had a mean volume of $7.87 \mathrm{~cm}^{3}$ $(\mathrm{SE}=2.11, \mathrm{n}=5)$, a dry weight of $1.21 \mathrm{~g}(\mathrm{SE}=0.099)$ and an ash-free dry mass (AFDM) of $0.61 \mathrm{~g}$ (SE = 0.064 ). At $-1.5^{\circ} \mathrm{C}$ mean oxygen consumption was

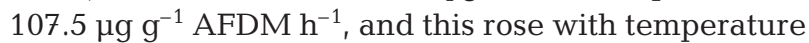
to a maximum of $300.1 \mathrm{\mu g} \mathrm{g}^{-1} \mathrm{AFDM} \mathrm{h}^{-1}$ at $12^{\circ} \mathrm{C}$ before declining rapidly at $15^{\circ} \mathrm{C}$ (Fig. 2). At this point specimens began to die and the experiment was terminated. In a Generalised Linear Model (GLM) analysis temperature had a significant effect on oxygen consumption $\left(F_{1,196}=37, \mathrm{p}<0.001\right)$, as did individual $\left(F_{1,196}=22.4\right.$, $\mathrm{p}<0.001)$, but the interaction term was not significant $\left(F_{1,196}=0.01, p=0.91\right)$. A Tukey comparison of means showed that rates of oxygen consumption at different temperatures were significantly different $(p=0.05)$ for all pairwise comparisons with the exception of $-1.5^{\circ} \mathrm{C}$

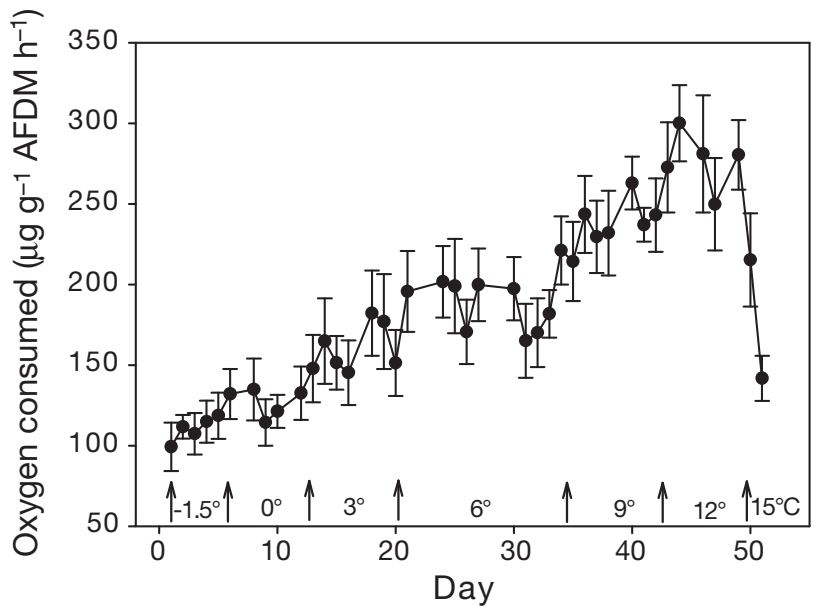

Fig. 2. Odontaster validus. Oxygen consumption in relation to temperature. Five specimens were held initially at $-1.5^{\circ} \mathrm{C}$, and then temperatures were raised incrementally to $0,3,6,9,12$ and $15^{\circ} \mathrm{C}$. Temperatures were raised after oxygen consumption values had appeared to stabilise. Arrows indicate days when temperatures were changed. Data shown are mean values for the group $\pm \mathrm{SE}$. Experiments were terminated when more than $50 \%$ of the starfish died. AFDM: ash-free dry mass

vs. $0^{\circ} \mathrm{C}$ and $9^{\circ} \mathrm{C}$ vs. $12^{\circ} \mathrm{C}$. The oxygen consumption rate at $15^{\circ} \mathrm{C}$ was significantly lower than the value at $12^{\circ} \mathrm{C}$. $Q_{10}$ values for each temperature step between -1.5 and $12.0^{\circ} \mathrm{C}$ were $3.1\left(-1.5\right.$ to $\left.0^{\circ} \mathrm{C}\right), 2.3\left(0\right.$ to $\left.3^{\circ} \mathrm{C}\right), 1.7(3$ to $\left.6^{\circ} \mathrm{C}\right), 2.3\left(6\right.$ to $\left.9^{\circ} \mathrm{C}\right)$, and $1.29\left(9\right.$ to $\left.12^{\circ} \mathrm{C}\right)$. The overall $Q_{10}$ for the change in metabolic rate between -1.5 and $12^{\circ} \mathrm{C}$ was 1.95 . Control starfish held at $0^{\circ} \mathrm{C}$ without food for the whole experimental period survived for more than 1 mo after experimental trials ceased with no mortality, showing that the effects of starvation in these trials were small.

The oxygen concentration of coelomic fluid declined markedly from 6.9 to $4.1 \mathrm{mg} \mathrm{O} \mathrm{O}^{-1}$ at 1.5 and $0^{\circ} \mathrm{C}$, respectively (Fig. 3). When temperatures were raised initial measurements were made within $24 \mathrm{~h}$ of the temperature change to measure acute responses, and further measures were made 4 to $8 \mathrm{~d}$ after the temperature rise to assess acclimated responses. Acute coelomic oxygen concentrations leveled off at values of 2 to $3 \mathrm{mg} \mathrm{O}_{2} \mathrm{l}^{-1}$ between 3 and $12^{\circ} \mathrm{C}$. Acclimated values, on the other hand, increased significantly from these low values to 4.8 and $4.2 \mathrm{mg} \mathrm{O}_{2} \mathrm{l}^{-1}$ at 0 and $3^{\circ} \mathrm{C}$ $(t=3.2, \mathrm{p}<0.05 ; t=4.8, \mathrm{p}<0.01)$, respectively. Recovery was poorer at $6^{\circ} \mathrm{C}$, with only a value just below $3 \mathrm{mg} \mathrm{O}_{2} \mathrm{l}^{-1}$ being achieved (only ca. $0.5 \mathrm{mg} \mathrm{O}_{2} \mathrm{l}^{-1}$ higher than acute values). At 9 and $12^{\circ} \mathrm{C}$ the acclimated coelomic oxygen concentrations were lower than the acute measures, but values overlapped. At $15^{\circ} \mathrm{C}$ coelomic oxygen concentration collapsed to close to 0 , indicating an inability to maintain oxygen supply to the tissues. 


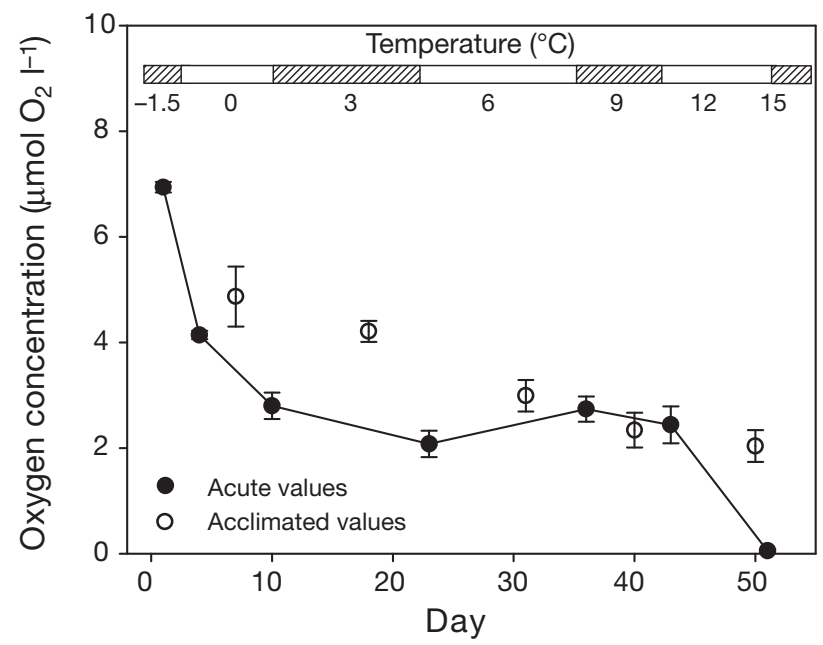

Fig. 3. Odontaster validus. Oxygen content of coelomic fluid with temperature. Each data point represents the mean for the 3 specimens measured at each temperature (each value was the mean of triplicate measures per individual). $\mathbf{0}$ : acute values taken within $24 \mathrm{~h}$ of the temperature being raised; O: acclimated values taken between 4 and $7 \mathrm{~d}$ after the temperature was raised. Note that there was no compensation (sensu Precht et al. 1955) of acclimated values from acute levels at temperatures of $6^{\circ} \mathrm{C}$ and above

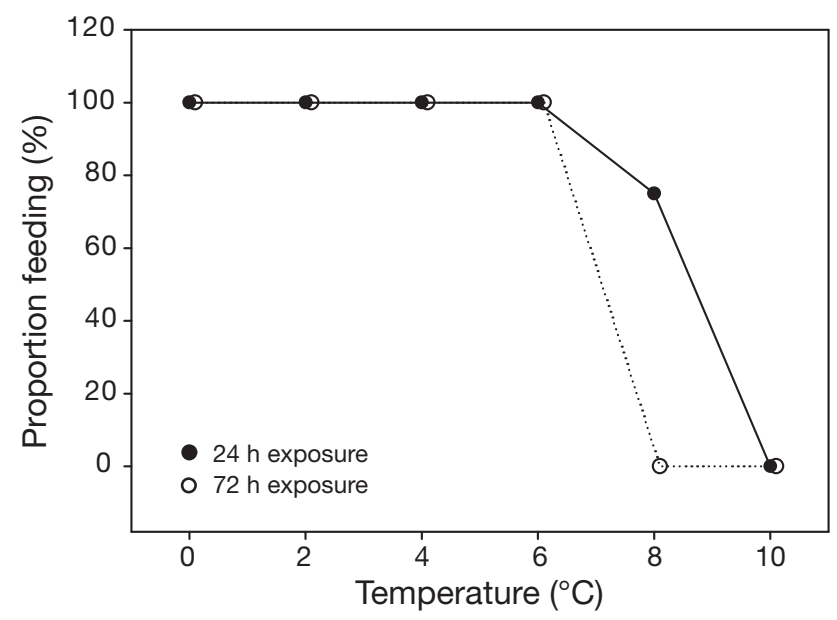

Fig. 4. Odontaster validus. Proportion of starfish $(n=8)$ feeding 24 and $48 \mathrm{~h}$ after being offered food in relation to temperature. : offered food after $24 \mathrm{~h}$ exposure to the experimental temperature; O: counts for separate starfish offered food after $72 \mathrm{~h}$ at the set temperature

\section{Feeding, SDA and temperature}

All starfish acclimated for $24 \mathrm{~h}$ at the set temperatures, fed immediately when offered food, and were still feeding $24 \mathrm{~h}$ later at $0,2,4$ and $6^{\circ} \mathrm{C}$ (Fig. 4). At $8^{\circ} \mathrm{C}$ all starfish accepted food when offered, but $24 \mathrm{~h}$ later only 6 of the 8 were still feeding. When starfish acclimated for $3 \mathrm{~d}$ at $8^{\circ} \mathrm{C}$ were tested, none fed. At $10^{\circ} \mathrm{C}$ no starfish fed after $24 \mathrm{~h}$ or $3 \mathrm{~d}$ exposure.
Table 1. Odontaster validus. Size data (volume, wet weight, dry weight, and ash-free dry mass [AFDM]) for starfish held at 0 and $6^{\circ} \mathrm{C}$ in the Specific Dynamic Action (SDA) experiment. All values are mean $\pm \mathrm{SEM}$. Starfish held at $6^{\circ} \mathrm{C}$ were significantly larger than those at $0^{\circ} \mathrm{C}(t$-test on volume: $t=$ 6.03, df $=9, \mathrm{p}<0.001$ )

\begin{tabular}{|lcccc}
\hline $\begin{array}{l}\text { Temp. } \\
\left({ }^{\circ} \mathrm{C}\right)\end{array}$ & $\begin{array}{c}\text { Volume } \\
\left(\mathrm{cm}^{3}\right)\end{array}$ & $\begin{array}{c}\text { Wet weight } \\
(\mathrm{g})\end{array}$ & $\begin{array}{c}\text { Dry weight } \\
(\mathrm{g})\end{array}$ & $\begin{array}{c}\text { AFDM } \\
(\mathrm{g})\end{array}$ \\
\hline 0 & $5.46 \pm 0.38$ & $5.30 \pm 0.33$ & $1.19 \pm 0.07$ & $0.64 \pm 0.04$ \\
6 & $11.28 \pm 0.89$ & $11.76 \pm 0.94$ & $2.23 \pm 0.18$ & $1.34 \pm 0.12$ \\
\hline
\end{tabular}

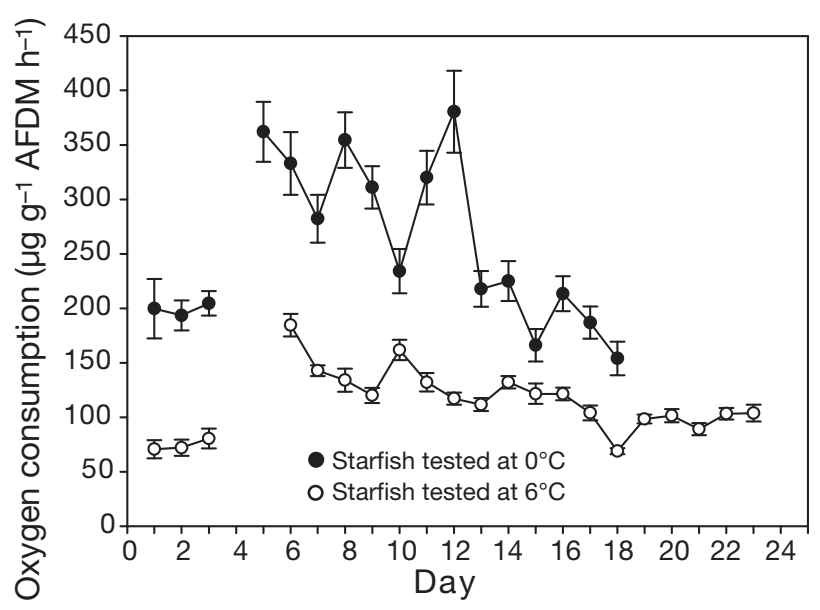

Fig. 5. Odontaster validus. Oxygen consumption in relation to feeding for starfish held at 0 and $6^{\circ} \mathrm{C}$. At both temperatures starfish were fed on Day 3 after oxygen consumption measures had started. O: starfish tested at $0^{\circ} \mathrm{C}_{i} \bullet$ : starfish tested at $6^{\circ} \mathrm{C}$. AFDM: ash-free dry mass

SDA trials were run at 0 and $6^{\circ} \mathrm{C}$, the latter because this was the highest temperature in feeding trials where all starfish fed. Starfish were chosen at random from the holding stock, but specimens used were larger in the $6^{\circ} \mathrm{C}$ trials than in the $0^{\circ} \mathrm{C}$ ones (Table 1). Because the sizes of the starfish were different, but not markedly so, pre- and post-prandial metabolic rates were expressed on a mass-specific basis.

At $0^{\circ} \mathrm{C}$ standard metabolic rate was $78.5 \mu \mathrm{g} \mathrm{O}_{2} \mathrm{~g}^{-1}$ $\mathrm{AFDM} \mathrm{h}^{-1}$. After feeding, oxygen consumption rose to a peak $181 \mathrm{\mu g} \mathrm{g}^{-1}$ AFDM h ${ }^{-1}$, a factorial rise of $\times 2.30$ (Fig. 5). Oxygen consumption remained elevated above pre-feeding for $15 \mathrm{~d}$. At $6^{\circ} \mathrm{C}$ pre-prandial standard metabolic rate was $194.2 \mu \mathrm{g} \mathrm{O}_{2} \mathrm{~g}^{-1} \mathrm{AFDM} \mathrm{h}^{-1}$ and the post-prandial peak was $372.0 \mu \mathrm{g}_{2} \mathrm{~g}^{-1}$ $A F D M h^{-1}$, a rise of $\times 1.92$. The post-prandial rise in metabolism remained elevated above pre-feeding levels for $10 \mathrm{~d}$. 


\section{DISCUSSION}

\section{Activity and temperature}

Recent studies by Gonzalez-Cabrera et al. (1995), Lowe \& Davison (2005), Jin \& DeVries (2006) and Podrabsky \& Somero (2006) have shown that a range of Antarctic fish species are capable of acclimating and functioning long-term to a temperature of $4^{\circ} \mathrm{C}$, with enhanced thermal tolerance when temperatures are subsequently raised acutely to values in excess of $10^{\circ} \mathrm{C}$. In contrast, Peck et al. (2004) showed that Antarctic limpets, clams and scallops rapidly lose the ability to perform work in the face of increasing temperatures. At temperatures of $5^{\circ} \mathrm{C}$ the limpet and clam were incapable of righting and burying, respectively, and at 2 to $3^{\circ} \mathrm{C} 50 \%$ of the individuals studied failed to right or bury. The scallop was even more tightly constrained with no specimens capable of swimming at $2{ }^{\circ} \mathrm{C}$. Recently this limitation to activity has been shown to be an oxygen supply dependency, because lowering or raising ambient oxygen levels lowered and raised, respectively, the successful performance of burying activity in the clam Laternula elliptica (Peck et al. 2007). Furthermore attempts to acclimate various Antarctic invertebrate species to $3^{\circ} \mathrm{C}$ have failed for the scallop Adamussium colbecki (Bailey et al. 2005). Upper temperature limits for brachiopods have been shown to be between 3.0 and $4.5^{\circ} \mathrm{C}$ (Peck 1989) and for the bivalve Limopsis marionensis to be below $4^{\circ} \mathrm{C}$ (Pörtner et al. 1999a). The clam L. elliptica (S. Morley pers. comm.) and the brittle star Ophioniotus victoriae (M. Clark pers. obs.) cannot acclimate to $3.0^{\circ} \mathrm{C}$. These measures of ability to perform activity and capacity to acclimate to elevated temperatures are better predictors of the ability of a species to cope in a changing environment than earlier studies of purely upper lethal limits, which in themselves showed Antarctic marine species to be highly stenothermal (Somero \& DeVries 1967, Peck \& Conway 2000).

Data here showing that all Odontaster validus studied were capable of performing activity up to $7^{\circ} \mathrm{C}$, and the vast majority up to $9.5^{\circ} \mathrm{C}$, are markedly different from data for other Antarctic marine invertebrates (Peck et al. 2004). This indicates that this species is significantly more eurythermal than previous invertebrate species studied. This is the first echinoderm to be evaluated in this way, and it is possible that there is a taxonomic effect here, especially as Antarctic fish appear more capable of acclimation than the invertebrates investigated, or there may be a bauplan effect.

Rates of activity in Odontaster validus increased with temperature monotonically from $0.21 \mathrm{~min}^{-1}$ at $0^{\circ} \mathrm{C}$ to $0.41 \mathrm{~min}^{-1}$ at $7^{\circ} \mathrm{C}$, where they peaked before complete failure at $11^{\circ} \mathrm{C}$. The increase produces a $Q_{10}$ of 2.71 for the temperature effect on activity, which is well within the expected range for biological functions. This type of relationship, increasing activity up to a maximum followed by a decline, is widespread in marine ectotherms and may be a characteristic of animals in general. In polar species this has been shown for the infaunal clam Laternula elliptica (Morley et al. 2007), where a maximum rate that was closer to upper critical temperature limits, and is also above the normally experienced range of temperatures, was also found. However, maximum activity rates occurred at 2 to $3^{\circ} \mathrm{C}$ in L. elliptica, a much lower temperature than that for O. validus. Lower temperatures for maximum activity rates would also be expected in the scallop Adamussium colbecki, the brittle star Ophionotus victoriae and the limpet Nacella concinna, as their upper limits for activity are $5^{\circ} \mathrm{C}$ or lower. O. validus activity is also markedly different from the changes demonstrated by the Antarctic fish Pagothenia borchgrevincki. Although the latter can survive up to $10^{\circ} \mathrm{C}$, has its maximum thermal scope measured at $3^{\circ} \mathrm{C}$, and swimming performance follows a similar pattern (Wilson et al. 2002, Lowe \& Davison 2005).

\section{Oxygen consumption and temperature}

Oxygen consumption in Odontaster validus rose consistently with temperature (Fig. 2) in a similar fashion to the pattern seen for Laternula elliptica (Peck et al. 2002), the limpet Nacella concinna, and the brachiopod Liothyrella uva (Peck 1989). The rise from a mean oxygen consumption of $106 \mu \mathrm{g} \mathrm{O}_{2} \mathrm{~g}^{-1} \mathrm{AFDM} \mathrm{h}{ }^{-1}$ at $-1.5^{\circ} \mathrm{C}$ to $281 \mu \mathrm{O} \mathrm{O}_{2} \mathrm{~g}^{-1} \mathrm{AFDM} \mathrm{h}{ }^{-1}$ at $12^{\circ} \mathrm{C}$ produces a $Q_{10}$ of 2.06 and is in the range of typical effects of temperatures on biological systems. As with previous investigations a rise to a peak is followed by a rapid fall in oxygen consumption and death of the specimens under study. This matches the predictions of the oxygen limitation of thermal tolerance (Pörtner 2002), where a failure in oxygen supply mechanisms is the proximate mechanism causing death. The difference in these data from previous studies on Antarctic ectotherms is that the $O$. validus survived up to $12^{\circ} \mathrm{C}$, whereas the limpet $N$. concinna and the bivalve mollusc $L$. elliptica failed at ca. $9^{\circ} \mathrm{C}$, and the brachiopod L. uva and the bivalve Limopsis marionensis did not survive above $4.5^{\circ} \mathrm{C}$ (Peck 1989, Pörtner et al. 1999a, Peck et al. 2002).

It is interesting that coelomic oxygen content increased in short-term acclimated specimens over acute values at 0,3 and $6^{\circ} \mathrm{C}$, but not at $9^{\circ} \mathrm{C}$ (Fig. 3). Combined with the results showing that activity was maintained up to $9^{\circ} \mathrm{C}$, this suggests that the upper pejus temperature (sensu Pörtner 2002) is around this temperature. This also matches previous studies that have 
found the pejus temperature to be a few degrees below the upper thermal limit in Antarctic marine species (Pörtner et al. 2007). These data would also suggest that Odontaster validus should be able to acclimate to temperatures possibly as high as $6^{\circ} \mathrm{C}$, and that this is one of the most, if not the most, eurthermal Antarctic marine species investigated to date.

\section{Feeding, metabolism and temperature}

In line with the above data showing that Odontaster validus can perform physical activity up to $9^{\circ} \mathrm{C}$ in medium-term temperature elevation experiments and can survive temperatures up to $12^{\circ} \mathrm{C}$ with similar rates of rising temperature, it would be expected that it would maintain its ability to feed at temperatures well above those experienced in its natural environment $\left(-1.8\right.$ to $1.8^{\circ} \mathrm{C}$ at Rothera station). All specimens in trials up to $6^{\circ} \mathrm{C}$ fed immediately on food made available and continued to feed $3 \mathrm{~d}$ later (Fig. 4). At $8^{\circ} \mathrm{C}$ nearly $80 \%$ of individuals fed over the first $24 \mathrm{~h}$ of reaching the set temperature, but none were feeding after $3 \mathrm{~d}$. No specimens fed at $10^{\circ} \mathrm{C}$ at any time interval. These data again reinforce the implication that the upper pejus temperature for this species is between 8 and $10^{\circ} \mathrm{C}$, because this is the temperature range where the capacity to perform metabolic work (aerobic capacity) is lost. Again it should be noted that this upper limit for activity is above the upper survival limit for all Antarctic marine invertebrates so far reported.

The rise in metabolism following feeding is a ubiquitous response in animals, and it is termed the SDA or Heat Increment (HIF) of feeding. Two main measures are made of the SDA: the factorial rise from prefeeding to peak levels of oxygen consumption and the duration of the effect. In coldwater species the duration of the SDA is longer than for species at warmer temperatures, but the factorial rise is similar (Peck 1998). The overall energetic cost involved as a proportion of the energy content of the meal, the SDA coefficient, stays the same across temperatures.

The data in the present study for Odontaster validus match this pattern (Fig. 5). At $0^{\circ} \mathrm{C}$ the factorial rise to peak from pre-feeding levels was $\times 2.3$, and metabolism was raised for $15 \mathrm{~d}$. At $6^{\circ} \mathrm{C}$ the rise to peak was $\times 1.9$, and the SDA lasted $10 \mathrm{~d}$. However, it should be noted that specimens were only offered meals of $10 \%$ body mass, and both variation in rise to peak and larger peaks might have been obtained with larger meals. Despite the factorial SDA rise to peak being slightly larger at $0^{\circ} \mathrm{C}$, because the pre-feeding standard metabolic rate was higher at $6^{\circ} \mathrm{C}\left(194 \mu \mathrm{g} \mathrm{O} \mathrm{O}^{-1}\right.$ AFDM h ${ }^{-1}$ compared to $78.5 \mu g \mathrm{O}_{2} \mathrm{~g}^{-1}$ AFDM h $^{-1}$ at $0^{\circ} \mathrm{C}$ ), the actual rise in metabolism was greater at the higher temperature $\left(178 \mu \mathrm{g} \mathrm{O} \mathrm{O}^{-1}\right.$ AFDM h $\mathrm{h}^{-1}$ at $6^{\circ} \mathrm{C}$ compared to $102.5 \mu \mathrm{g} \mathrm{O}_{2} \mathrm{~g}^{-1} \mathrm{AFDM} \mathrm{h}^{-1}$ at $0^{\circ} \mathrm{C}$ ). This explains the reduction in duration of the SDA at $6^{\circ} \mathrm{C}$, as similar amounts of total energy were used in the overall SDA (area under the curve in Fig. 5). Interestingly, the SDA at both 0 and $6^{\circ} \mathrm{C}$ appeared to be composed of 3 phases. At $0^{\circ} \mathrm{C}$ the peaks on each phase declined in size, but each phase was progressively longer, whereas at $6^{\circ} \mathrm{C}$ peaks were the same height and durations were also similar. Mulitple peaks in an SDA have been reported previously for the limpet Nacella concinna (Peck \& Veal 2001) and the nemertean Parborlasia corrugatus (Clarke \& Prothero-Thomas 1997). The latter authors also noted that different metabolic processes occurred at different times during the SDA cycle. Thus, urea excretion was predominantly associated with the last phase.

\section{Physiological and ecological implications}

The fact that Odontaster validus survives in mediumterm warming trials to at least $12^{\circ} \mathrm{C}$, continues to perform activity up to $9^{\circ} \mathrm{C}$, can complete a full feeding cycle and appears able to recover its coelomic fluid oxygen content with acclimation at $6^{\circ} \mathrm{C}$ indicates that this is easily the most eurythermal Antarctic marine invertebrate so far studied, and it may be the most eurythermal of all Antarctic marine ectotherms to date, including fish. The possible reasons for this include taxonomic effects or physiological constraints, although taxonomic constraints seem unlikely as clams, scallops, limpets and brittle stars are highly temperature sensitive. It may, however, be possible to explain these data via the oxygen limitation hypothesis (Pörtner 2002, Pörtner et al. 2007). Under this hypothesis, oxygen use, availability and delivery dictate rate of loss of aerobic scope with rising temperature. Fish have much higher levels of oxygen carrying blood pigments than either molluscs or fish, and their delivery system (the circulatory system) is more efficient. Thus, aerobic scope loss may be less in fish because of an enhanced delivery system. The major tissue in animals in terms of oxygen demand is muscle because of its mitochondrial content and the activity functions it performs. Muscle mass relative to whole animal mass is much lower in $O$. validus than in either molluscs or fish. Thus the loss of aerobic scope in the starfish with warming may be less than in other groups because its main locomotory mechanism is not muscle-based. Animals with poor circulatory capacities and larger muscle masses, such as scallops, would therefore be more vulnerable to environmental warming than those with better oxygen delivery systems or those with lower relative muscle mass. 
The success of Odontaster validus in surviving elevated temperatures is clearly important given the $1{ }^{\circ} \mathrm{C}$ rise in sea temperatures observed in the Bellingshausen Sea off the Antarctic peninsula over the last 50 yr (Meredith \& King 2005). However, other considerations than the direct survival of this species may be of more interest. In ecological terms the success of a starfish predator at temperatures well above those where some of its known prey fail has a significant potential impact at community and ecosystem levels. All 3 mollusc species studied by Peck et al. (2004) lost significant capacity to perform activity at 2 to $3^{\circ} \mathrm{C}$. The clam Laternula elliptica avoids predators such as $O$. validus by burying in sediment, while swimming is the scallop's main mechanism of predator avoidance. Rates of activity and processing meals increase in O. validus, at least to $6^{\circ} \mathrm{C}$. Thus the ability of the prey species to avoid $O$. validus will decrease with every rise in temperature above the current position, because their ability to perform activity declines more rapidly with rising temperature than does that of the starfish. It is these types of change in ecological balance that are the most likely mechanisms for extinction of species at the population level (Peck 2005). This is the first evaluation of the capacity of a predatory benthic Antarctic invertebrate to continue to perform biological functions in elevated temperatures. The fact that it is far more capable than previously studied suspension-feeders or grazers raises important questions that need urgent attention. Are Antarctic marine benthic predators in general better at coping with rising temperatures, and thus could ecological imbalance be caused by relatively minor temperature changes? Or are the data here phenomena that are peculiar to starfish predators or even to $O$. validus itself, and if so why? Clearly such questions of differing capacities to cope among different feeding guilds are of wide significance in all major marine ecosystems and not just Antarctica.

Acknowledgements. We thank the support team at the British Antarctic Survey Rothera research station, especially the dive team. Diving support was also given by the NERC National Facility for Scientific Diving at Oban. We also thank S. Morley for constructive criticism.

\section{LITERATURE CITED}

Arntz WE, Brey T, Gallardo VA (1994) Antarctic zoobenthos. Oceanogr Mar Biol Annu Rev 32:241-304

Bailey DM, Johnston IA, Peck LS (2005) Invertebrate muscle performance at high latitude: swimming activity in the Antarctic scallop Adamussium colbecki. Polar Biol 28: 464-469

Chapelle G, Peck LS (1995) The influence of acclimation and substratum on the metabolism of the Antarctic amphipods Waldeckia obesa (Chevreux 1905) and Bovallia gigantea (Pfeffer 1888). Polar Biol 15:225-232
Clarke A, Johnston NM (2003) Antarctic marine benthic diversity. Oceanogr Mar Biol Annu Rev 41:47-114

Clarke A, Prothero-Thomas E (1997) The influence of feeding on oxygen consumption and nitrogen excretion in the antarctic nemertean parborlasia corrugatus. Physiol Zool 70:639-649

Gonzalez-Cabrera PJ, Dowd F, Pedibhotla VK, Rosario R, Stanley-Samuelson D, Petzel D (1995) Enhanced hypoosmoregulation induced by warm acclimation in Antarctic fish is mediated by increased gill and kidney $\mathrm{Na}^{+} / \mathrm{K}^{+}$ATPase activities. J Exp Biol 198:2279-2291

Jin Y, DeVries A (2006) Antifreeze glycoprotein levels in Antarctic notothenioid fishes inhabiting different environments and the effect of warm acclimation. Comp Biochem Physiol B 144:290-300

Lowe CJ, Davison W (2005) Plasma osmolarity, glucose concentration and erythrocyte responses of two Antarctic nototheniid fishes to acute and chronic thermal change. J Fish Biol 67:752-766

Meredith MP, King JP (2005) Rapid climate change in the ocean west of the Antarctic peninsula during the second half of the 20th century. Geophys Res Lett 32:L19604

Morley SA, Peck LS, Tan KS, Martin SM, Pörtner HO (2007) Morphological temperature compensation maintains burrowing capacity: a latitudinal comparison in the bivalve Laternula. Mar Biol 151:1823-1830

Peck LS (1989) Temperature and basal metabolism in two Antarctic marine herbivores. J Exp Mar Biol Ecol 127: $1-12$

Peck LS (1996) Metabolism and feeding in the Antarctic brachiopod Liothyrella uva: a low energy lifestyle species with restricted metabolic scope. Proc R Soc Lond B Biol Sci 263:223-228

Peck LS (1998) Feeding, metabolism and metabolic scope in Antarctic ectotherms. Soc Experimental Biol Seminar Ser 66:365-389

Peck LS (2005) Prospects for survival in the Southern ocean: extreme temperature sensitivity of benthic species. Antarct Sci 17:497-507

Peck LS, Conway LZ (2000) The myth of metabolic cold adaptation: oxygen consumption in stenothermal Antarctic bivalves. In: Harper E, Tatlor JD, Crame JA (eds) Evolutionary biology of the bivalvia, Vol 177. Geological Society Special Publications, London, p 441-450

Peck LS, Uglow RF (1990) Two methods for the assessment of oxygen content of small seawater samples. J Exp Mar Biol Ecol 141:53-62

> Peck LS, Veal R (2001) Feeding, metabolism and growth in the Antarctic limpet Nacella concinna (Strebel 1908). Mar Biol 138:553-560

Peck LS, Whitehouse MJ (1992) An improved desorber design for couloximetry. J Exp Mar Biol Ecol 163:163-167

Peck LS, Pörtner HO, Hardewig I (2002) Metabolic demand, oxygen supply and critical temperatures in the Antarctic bivalve Laternula elliptica. Physiol Biochem Zool 75: 123-133

> Peck LS, Webb K, Bailey D (2004) Extreme sensitivity of biological function to temperature in Antarctic marine species. Funct Ecol 18:625-630

Peck LS, Morley SA, Portner HO, Clark MS (2007) Small increases in temperature and reductions in oxygen availability limit burrowing capacity in the Antarctic clam Laternula elliptica. Oecologia 154:479-484

Podrabsky JE, Somero GN (2006) Inducible heat tolerance in Antarctic notothenioid fishes. Polar Biol 30:39-43

Pörtner HO (2002) Climate variations and the physiological basis of temperature dependent biogeography: systemic 
to molecular hierarchy of thermal tolerance in animals. Comp Biochem Physiol A 132:739-761

Pörtner HO, Hardewig I, Sartorius FJ, van Dijk PLM (1998) Energetic aspects of cold adaptation: critical temperatures in metabolic, ionic and acid-base regulation? In: Pörtner HO, Playle R (eds) Cold ocean physiology. Cambridge University Press, Cambridge, p 88-120

Pörtner HO, Peck LS, Zielinski S, Conway LZ (1999a) Intracellular $\mathrm{pH}$ and energy metabolism in the highly stenothermal Antarctic bivalve Limopsis marionensis as a function of ambient temperature. Polar Biol 22:17-30

Pörtner HO, Hardewig I, Peck LS (1999b) Mitochondrial function and critical temperature in the Antarctic bivalve Laternula elliptica. Comp Biochem Physiol A 124: 179-189

Editorial responsibility: Otto Kinne,

Oldendorf/Luhe, Germany
Pörtner HO, Somero GN, Peck LS (2007) Thermal limits and adaptation: an integrated view. Phil Trans R Soc Lond B 362:2233-2258

Precht H, Christophersen J, Hensel H (1955) Temperatur und Leben. Springer, Berlin

Seebacher F, Davison W, Lowe CJ, Franklin CE (2005) A falsification of the thermal specialization paradigm: compensation for elevated temperatures in Antarctic fishes. Biol Lett 1:151-154

Somero GN, DeVries AL (1967) Temperature tolerance of some Antarctic fishes. Science 156:257-258

Wilson RS, Kuchel LJ, Franklin CE, Davison W (2002) Turning up the heat on subzero fish: thermal dependence of sustained swimming in an Antarctic notothenioid. J Therm Biol 27:381-386

Submitted: September 18, 2007; Accepted: November 15, 2007 Proofs received from author(s): April 2, 2008 